\title{
A Classification Approach for Corrosion Rating of Soil to Buried Water Pipelines: A Case Study in Budhanilkantha-Maharajganj Roadway Areas of Nepal
}

\author{
Abiral Poudel, Kumar Prasad Dahal, Dinesh K. C., Jagadeesh Bhattarai* \\ Central Department of Chemistry, Tribhuvan University, Kirtipur, Nepal \\ Email address: \\ bhattarai_05@yahoo.com (J. Bhattarai) \\ ${ }^{*}$ Corresponding author \\ To cite this article: \\ Abiral Poudel, Kumar Prasad Dahal, Dinesh K. C., Jagadeesh Bhattarai. A Classification Approach for Corrosion Rating of Soil to Buried \\ Water Pipelines: A Case Study in Budhanilkantha-Maharajganj Roadway Areas of Nepal. World Journal of Applied Chemistry. \\ Vol. 5, No. 3, 2020, pp. 47-5. doi: 10.11648/j.wjac.20200503.12
}

Received: August 13, 2020; Accepted: August 24, 2020; Published: October 22, 2020

\begin{abstract}
The present study was focused to estimate six characteristics of soil specimens taken from 0.3 to $1.5 \mathrm{~m}$ sampling depth of six sampling sites of Budhanilkantha-Maharajganj roadsides using standard methods, and was assessed their corrosive nature to the buried-metallic pipelines using an empirical corrosion rating model. The estimated soil $\mathrm{pH}$, moisture, resistivity, redox potential (ORP), chloride and sulfate ions were 6.4-7.9, 7-45\%, $4.5 \times 10^{3}-45.5 \times 10^{3} \mathrm{Ohm} . \mathrm{cm}, 317-514 \mathrm{mV}$ (SHE), 12$86 \mathrm{ppm}$, and 40-294 ppm, respectively, in all the soil sample specimens. The experimental results indicated that the soils could be rated as mildly corrosive to less corrosive groups to the buried galvanized-steel and cast iron pipes in the study areas. A good positive or negative correlation coefficient between resistivity, moisture, chloride and sulfate contents implies that these soil parameters have an equal contribution to the rating of soil corrosivity. A polyethylene-sheet wrapping (i.e., encasement) around the galvanized-steel and cast iron water pipelines or the use of non-conducting materials of gravel/sand around the burying ground could be sufficient for the extension of their life up to 50 years or more. The empirical model is successfully applied for the corrosion rating of soil samples and could be progressive in the future for soil corrosion rating of soils to the underground waterworks. Present findings would be insightful and suggestive in making the corrosive land maps of the studied areas which would be helpful for the potable water pipeline works in other urban areas of Nepal.
\end{abstract}

Keywords: Buried-pipelines, Empirical Model, Salt Ions, Soil Resistivity, Sub-corrosive Group, Water Amount

\section{Introduction}

A notable impact and consequences in the maintenance and operations of any buried-pipelines from soil corrosion is noticed world widely, mostly by parameters of disturbed-soils [1]. It is presumed that the undisturbed-soil is a less corrosive nature than the disturbed ones [2]. Some of the key factors which affect such corrosion by the disturbed-soils to the buried-metallic pipelines to supply city water are moisture-holding capacity, acidity/alkalinity, electrical conductivity/resistivity and potential, salt ions concentration, aeration [3-11], and other factors like soil depth, topography, etc $[12,13]$. However, an estimation of soil corrosivity extent is often more difficult to classify as a concern to adjoining soil properties and materials of the pipelines, mostly due to its exceptionally high heterogeneity and localized complexity [14]. About a $27-30 \%$ increase in water pipeline damaged by aggressive soil factors is reported in the USA and Canada alone [15]. Moreover, about $10 \%$ of the annual corrosion cost in Australia is covered by buried-metallic pipelines corrosion [16]. The pipeline failures, mostly due to corrosive soil environments, are still growing at an alarming rate even with the applications of different corrosion protection techniques [17-19].

Drinking water is mostly supplied through the galvanizedsteel or/and cast iron pipelines in Nepal for a long period [2022], even though a very few are practiced to use of high-density plastic (HDP) pipelines in recent years. A damage of such buried-metallic pipelines causes a high degree of economic and environmental consequences, especially in urban areas of Kathmandu valley. Therefore, it is significant to understand 
accurately the corrosive nature of each soil factors causing the corrosion of such buried pipes and hence possible to apply an appropriate corrosion control techniques before installation of new water supply metallic-pipelines which can safely operate for a long time, i.e., a reliable 50-year service life.

Some of the widely accepted and have been used classification methods to evaluate the corrosive nature of the soil to buried-metallic pipelines are ASTM [23-25], NACE [26, 27] and ANSI/AWWA $[28,29]$. The ASTM and NACE systems are practiced previously to assess the degree of soil corrosivity to the buried-metallic pipelines [30-36]. In both the ASTM and NACE systems, the electrical conductivity/resistivity of soils is believed as the most important parameter for the evaluation of the buried-pipe corrosion, although the effects of other physicochemical soil parameters take account of less significance. However, the level of soil corrosivity is highly dependent on the experimental conditions, the topography, and other physico-chemical characteristics including the conductivity/resistivity of soil samples.

On the other hand, the 10-point system for the evaluation of the soil corrosion is considered in the AWWA system in which the electrical conductivity/resistivity again appears relevant, although other factors may be pertinent where the difference in corrosion rate is experience. The main drawbacks of the 10-point scoring system do not deal with nonlinear relationships among the soil factors. Apart from, scoring methods neglect some factors, i.e., the corrosive effect of chloride and sulfate ions that are critical to the deteriorating rate of the metallic pipelines in soils. The soil corrosion does not quantify by the 10-points method, and it classifies only two groupings of soil corrosivity, i.e., corrosive and non-corrosive only, not other intermediate levels of soil corrosivity. The soils less than 10 points consider as non-corrosive to ferrous/iron pipes, while the soil with 10 points or more consider as corrosive in the 10-point method $[28,29]$. Therefore, it does not sufficiently consider different soil corrosivity ratings to different types of buriedmetallic materials.

To address such drawbacks of the conventionally used systems, a new method based on the theory of probability is proposed herein for assessing more accurately the level of soil corrosion to the buried-metallic pipelines. In this comprehensive probabilistic model-based method, all important soil parameters are firstly estimated and then their cumulative effects are equally considered to evaluate the soil corrosion rating to the buried pipelines. The points assigned for each soil parameter summed to classify different corrosion levels and then to decide whether a special protective action should be applied for long term warranty of the buried-pipelines. The detail of the proposed method is described below in the experimental section.

In this context, the main objectives of the work are to estimate six parameters (i.e., soil moisture, $\mathrm{pH}$, resistivity, ORP, chloride, and sulfate contents) of thirty soil sample specimens collected from different sampling depths of each six sites in the vicinity of the Budanilkantha-Maharajganj roadway areas of Kathmandu district, to study the effects of depths on the soil corrosion behavior and to develop a predictive model for assessing of soil corrosion rating which could be addressed the viability of the corrosion protection strategy for the buried-galvanic steel and cast iron pipelines in the study areas.

\section{Experimental Methodology}

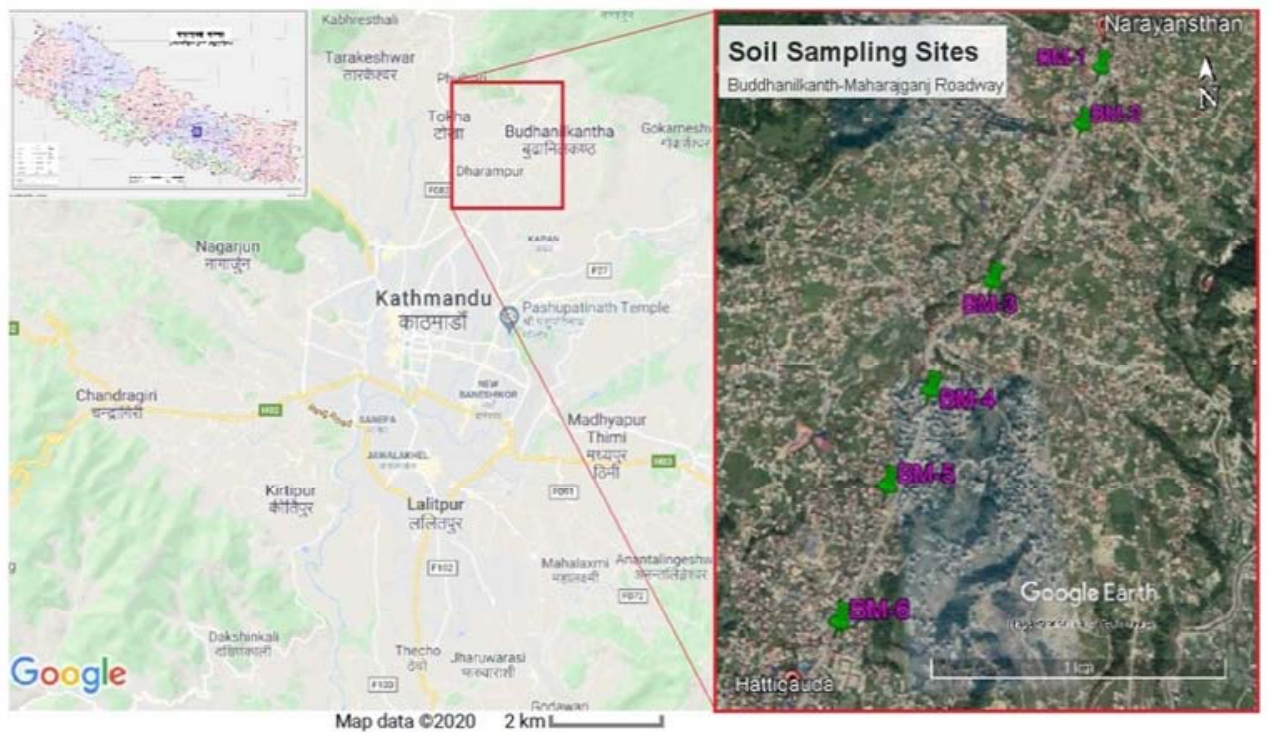

Figure 1. Google Earth map of soil sampling sites of Budhanilkantha-Maharajganj roadway areas.

First of all, six sampling sites were selected in the roadways of Budanilkantha-Maharajganj of the Kathmandu district (Figure 1) and then total thirty soil specimens were collected from each selected six sampling sites with the aid of soil auger from five depths (i.e., 0.3, 0.6, 1.0, 1.2 and 1.5 $\mathrm{m})$ below the ground level in February to May. Each soil 
sample specimens were taken in an airtight polyvinyl bag so that the moisture remained the same until their laboratory analysis. The six sampling sites are located within the $27^{\circ} 45^{\prime} 24.47^{\prime \prime} \mathrm{N}-27^{\circ} 46^{\prime} 35.03^{\prime \prime} \mathrm{N}$ latitude and $85^{\circ} 20^{\prime} 57.81$ "E$85^{\circ} 21^{\prime} 42.23^{\prime \prime} \mathrm{E}$ longitude as shown in Table 1.

Six soil parameters of the collected specimens were analyzed using standard methods as; the soil moisture was estimated using ASTM D4959-16 standard [37] in which the gravimetric technique is suggested. The $\mathrm{pH}$ and electrical conductivity of the 1:2 soil-water extract of each soil specimens were recorded using a digital $\mathrm{pH}$ meter and conductivity bridge, respectively, following by the ASTM standards [23, 38]. The soil resistivity was calculated from the recorded electrical conductance value [23].

The oxidation-reduction or redox potential (ORP) of the soil specimens was measured with the help of a digital potential-meter as described elsewhere [39]. A platinum wire mesh and saturated calomel electrode (SCE) were used as working and reference electrodes, respectively, for the recording of the ORP in $\mathrm{mV}$ with reference to SCE, and the recorded potential value was converted to a saturated hydrogen electrode (SHE) using equation (1), where, $\mathrm{E}_{\mathrm{SHE}}$ and $\mathrm{E}_{\mathrm{SCE}}$ are ORP with reference to saturated hydrogen electrode and saturated calomel electrode, respectively.

$$
\mathrm{E}_{\mathrm{SHE}}(\mathrm{mV})=\mathrm{E}_{\mathrm{SCE}}(\mathrm{mV})+242+59\left(\mathrm{pH}_{\text {soil }}-7\right)
$$

The argentometric (Mohr) titration based on the AASHTO T 291-94 standard [40] and a gravimetric titration based on the AASHTO T 290-95 standard [41] were followed to estimate the soluble ions of chlorides and sulfates, respectively, in the soil specimens. A 1:2 soil-water extract was titrated against the standard $\mathrm{AgNO}_{3}$ solution using potassium chromate as an indicator in the argentometric titration for the estimation of chloride ions in the samples.

Table 1. Geographical coordinates of the soil sampling sites.

\begin{tabular}{lll}
\hline Sample Sites & Latitude & Longitude \\
\hline BM-1 & $27^{\circ} 46^{\prime} 35.03^{\prime \prime} \mathrm{N}$ & $85^{\circ} 21^{\prime} 42.23^{\prime \prime} \mathrm{E}$ \\
BM-2 & $27^{\circ} 46^{\prime} 26.33^{\prime \prime} \mathrm{N}$ & $85^{\circ} 21^{\prime} 37.98^{\prime \prime} \mathrm{E}$ \\
BM-3 & $27^{\circ} 46^{\prime} 4.30^{\prime \prime} \mathrm{N}$ & $85^{\circ} 21^{\prime} 21.82$ "E \\
BM-4 & $27^{\circ} 45^{\prime} 50.53^{\prime \prime} \mathrm{N}$ & $85^{\circ} 21^{\prime} 11.71 " \mathrm{E}$ \\
BM-5 & $27^{\circ} 45^{\prime} 39.32^{\prime \prime} \mathrm{N}$ & $85^{\circ} 21^{\prime} 5.00^{\prime \prime} \mathrm{E}$ \\
BM-6 & $27^{\circ} 45 ' 24.47^{\prime \prime} \mathrm{N}$ & $85^{\circ} 20^{\prime} 57.81$ "E \\
\hline
\end{tabular}

A new predictive model for the assessment of the corrosion rating of soil samples to the buried- metallic pipelines was applied. In this model, all the analyzed six soil characteristics were estimated and they were classified into essentially less corrosive (ElC), mildly corrosive (MiC), moderately corrosive $(\mathrm{MoC})$ and severely corrosive (SevC) corresponds to I, II, III, and IV corrosion classes, respectively, as summarized in (Table 2). Then, their cumulative point (CP) for each four groups was taken into consideration for assessing ten sub-corrosive groups for rating of soil corrosion to the buried-galvanized steel and cast iron pipelines. Ten sub-corrosive groups are the essentially less corrosive (ElC), essentially less corrosive plus (ElC $\left.{ }^{\text {plus }}\right)$, mildly corrosive minus $\left(\mathrm{MiC}^{\text {minus }}\right)$, mildly corrosive $(\mathrm{MiC})$, mildly corrosive plus ( $\left.\mathrm{MiC}^{\mathrm{plus}}\right)$, moderately corrosive minus (MoC ${ }^{\text {minus }}$, moderately corrosive $(\mathrm{MoC})$, moderately corrosive plus (MoC $\left.{ }^{\text {plus }}\right)$, severely corrosive minus $\left(\mathrm{SevC} \mathrm{C}^{\mathrm{minus}}\right)$, and severely corrosive $(\mathrm{SevC})$ in this empirical model.

Table 2. Corrosivity level and corrosive group of the soil samples based on their properties.

\begin{tabular}{|c|c|c|c|c|c|}
\hline Soil factors & Corrosivity & Corrosion group & Soil factors & Corrosivity & Corrosion group \\
\hline \multicolumn{3}{|c|}{ Moisture (\%) [37] } & \multicolumn{3}{|l|}{ ORP (mV) [44] } \\
\hline $1-25$ & ElC & I & $>400$ & ElC & I \\
\hline $25-40$ & $\mathrm{MiC}$ & II & $200-400$ & $\mathrm{MiC}$ & II \\
\hline $40-60$ & $\mathrm{MoC}$ & III & $100-200$ & $\mathrm{MoC}$ & III \\
\hline$>60$ & SevC & IV & $<100$ & SevC & IV \\
\hline \multicolumn{3}{|l|}{$\mathrm{pH}_{\mathrm{aq}}[42]$} & \multicolumn{3}{|l|}{ Chloride (ppm) [36] } \\
\hline $6.6-7.5$ & ElC & I & $<50$ & ElC & I \\
\hline $5.4-4.0 ; 8.6-9.0$ & $\mathrm{MoC}$ & III & $200-400$ & $\mathrm{MoC}$ & III \\
\hline$>4.0$ & SevC & IV & $>400$ & $\mathrm{SC}$ & IV \\
\hline \multicolumn{3}{|c|}{ Resistivity $(\Omega . \mathrm{cm})[23,43]$} & \multicolumn{3}{|l|}{ Sulfate (ppm) [45] } \\
\hline$>10,000$ & ElC & I & $<100$ & ElC & I \\
\hline $5,000-10,000$ & $\mathrm{MiC}$ & II & $100-200$ & $\mathrm{MiC}$ & II \\
\hline $2,000-5,000$ & $\mathrm{MoC}$ & III & $200-500$ & $\mathrm{MoC}$ & III \\
\hline$<2,000$ & SevC & IV & $>500$ & SevC & IV \\
\hline
\end{tabular}

$\mathrm{ElC}=$ essentially less corrosive; $\mathrm{MiC}=$ mildly corrosive; $\mathrm{MoC}=$ moderately corrosive $\& \mathrm{SevC}=$ severely corrosive .

\section{Results and Discussion}

\subsection{Estimation of Soil Properties}

All the thirty soil specimens from different depths of each six sites show the $\mathrm{pH}$ values in the range of 7.1-8.6, as depicted in Figure 2 (a), which categorized the neutral and slightly alkaline soils according to the USDA standard [42].
It is reported that the acidic soil with $\mathrm{pH} 5$ or less is very corrosive to the buried-metallic materials [46]. In such acidic soils, especially the grey cast iron corroded remarkably higher than the galvanized-steel [16]. In general, the soils having 6.5-7.5 $\mathrm{pH}$ are considered as neutral and are essentially less corrosive (ElC) nature to the buriedgalvanized steel and cast iron pipelines [16]. On the other hand, the slightly alkaline nature of soil specimens having a 
$\mathrm{pH}$ between 7.6 and 8.5 is classified as mildly corrosive (MiC) according to the ASTM G51-18 standard [38]. Therefore, most of the soil specimens (about 80\%) among the thirty soil specimens are rated as $\mathrm{MiC}$, while remaining six soil specimens (i.e., 20\%) except one could be rated as ElC to the buried-galvanized steel and cast iron pipelines, as shown in Figure 2 (a). Moreover, there is not a clear relationship between the changes in soil $\mathrm{pH}$ values with sampling depth, and much the same results reported in the literature previously [11]. Such information provides us the information for predicting the buried-pipeline failures in the study areas and would help apply the appropriate corrosion controlling techniques in time.
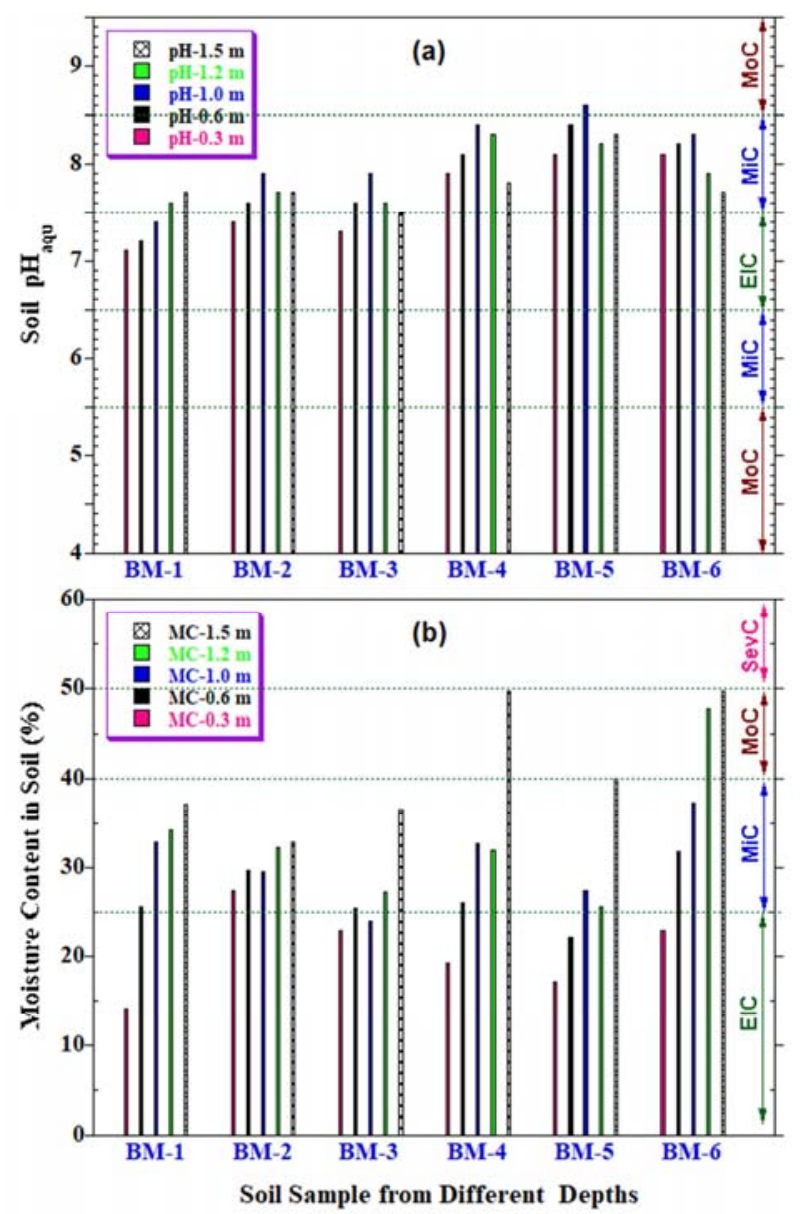

Figure 2. (a) soil pH and (b) moisture in sampling soil specimens taken from different depth.

The effect of sampling depth on the moisture in soil specimens was studied, and the result is presented in Figure 2 (b). All the thirty soil specimens, collected from different depths of each sampling site contained $14.15-49.71 \%$ moisture. The quantity of moisture in seven soil specimens (i.e., 23.3\%) among thirty is estimated less than $25 \%$ which could be rated as the ElC, while remaining soil specimens except three have $25-40 \%$ moisture, and thence they could be rated as $\mathrm{MiC}$ to the buried-galvanized steel and cast iron pipelines according to the ASTM D4959-16 standard [37]. These results disclosed the fact that major soil samples are assumed to be mildly corrosive and essentially less corrosive nature around the Budanilkantha-Maharajganj roadway areas.

The moisture in soil samples is generally increased with increasing the sampling depth in all six sites, as shown in Figure 2 (b). The maximum water-retaining capacity of the soil specimens is found in $1.5 \mathrm{~m}$ depth from the ground level, mostly due to the water table fluctuations. The water table fluctuation in soils is one of the important factors in assessing the soil corrosion rating which depends mainly on three factors; water flow patterns; ground topography, soil profiles, and soil type and water saturation limits [47]. In general, three types of waters affect the moisture-holding capacity of soil samples; gravitational, free ground and capillary waters [48]. The gravitational water generally reaches to the free groundwater table, especially in coarse-grained soils, although such coarse-grained sandy and coarse soils have less chance of capillary action. These facts support that the increase of soil moisture with sampling depth is mostly due to the free groundwater which is considered to be highly aggressive to the grounded metallic pipelines [49]. Moreover, the soil samples with high water holding capacity are the most corrosive to the buried-metallic materials, while a welldrained soil is less destructive [50-52]. The sandy soils with good drainage nature show very high resistivity and hence they could be rated as less corrosive for the buried-metallic materials.

Figure 3 (a) shows the results of soil resistivity of all analyzed soil specimens which are found in the range of 4,000-14,500 Ohm. cm. Among these thirty soil specimens, twenty-two specimens have 5,000-10,000 Ohm. cm resistivity which is considered as $\mathrm{MiC}$, only four sample specimens are considered as ElC with the resistivity values more than $10,000 \mathrm{Ohm}$. $\mathrm{cm}$ and remaining four soil specimens are rated as $\mathrm{MoC}$ having the soil resistivity of 4000-5000 Ohm. cm. Such a rating of soil corrosion is based on the resistivity value according to the ASTM standard [23, 43]. Literature reported that the ductile iron pipe with polyethylene encasement and cathodic protection is not likely to provide a reliable 50-year service life in severally corrosive (SevC) soils with $<2,000 \mathrm{Ohm}$. cm resistivity [53]. These results revealed that most of the soil samples (i.e., $73.4 \%$ ) collected from the sampling sites to be MiC, while half-half of the remaining $26.6 \%$ of the soil specimens could be rated as $\mathrm{MoC}$ and ElC. Consequently, it might be said that polyethylene encasement of the buried-galvanized steel and cast iron could be sufficient to save such pipelines for fifty years or more in the study areas. Besides, there is no clear correlation between the resistivity changes with sampling depth, although resistivity value is deceased with depth in most of the soil sampling sites. These results revealed that only variation of the soil sampling depth does not affect the corrosivity of soils to the buried-pipelines, which might be affected by other soil factors like moisture content, salt ions, etc.

Also, figure 3 (b) shows the variation of ORP values with five sampling depths of six sites. Fifteen specimens among thirty samples specimens could be rated as ElC 
with more than $+400 \mathrm{mV}$ (SHE) ORP, while it recorded between 315 and $395 \mathrm{mV}$ (SHE) in the remaining 15 soil sample specimens which are considered as MiC based on the ASTM G200-09 standard [39]. A similar relationship was firstly reported between ORP and soil corrosiveness by Starkey and Wight [44]. The ORP value generally affects the types of microbiologically induced corrosion (MIC) that occurs in soils [54, 55]. Sulfate is readily converted into highly corrosive sulfides by anaerobic sulfate-reducing bacteria-SRB $[56,57]$. It reported in the literature that the soil ORP value less than $+400 \mathrm{mV}$ (SHE) indicates a contributory environment for soil microbes with the reorganization of a substantial amount of sulfatereducing bacteria (SRB) which causes the formation of bio-film and thus increased the corrosion rate of the buried-metallic pipelines [6]. Besides, there is no correlation observed between the ORP values and the soil sampling depths.
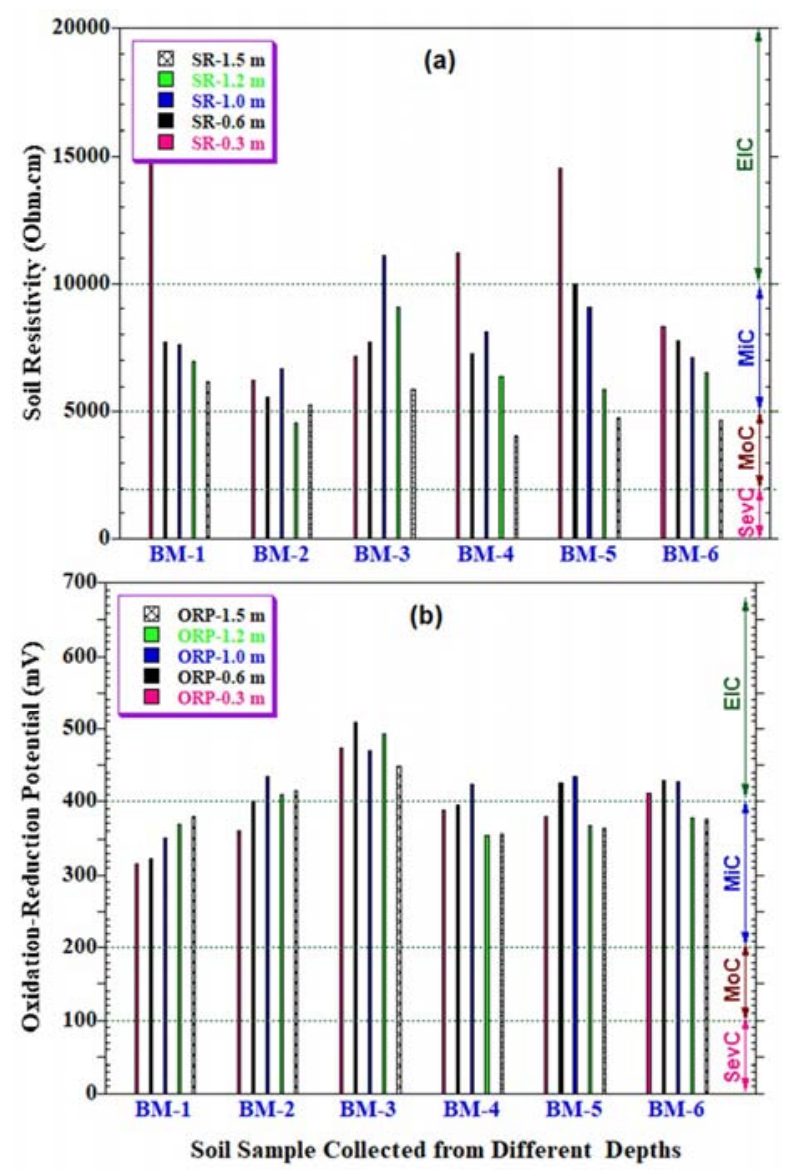

Figure 3. (a) Soil resistivity and (b) ORP values of the sampling soil specimens taken from different depth.

The estimated chloride and sulfate ions in all thirty soil specimens are in the range of about 25-63 ppm and 36-196 ppm, respectively, as depicted in Figure 4. Most of the analyzed soil samples except three contained less than 50 ppm chloride ions, as illustrated in Figure 4 (a), which could be suggested as essentially less corrosive (ElC) to the buriedgalvanized steel and cast iron pipelines. Only $10 \%$ of the analyzed soil sample specimens are considered to be mildly corrosive (MiC) based on the estimated amount of chloride ions in soil samples [36]. Furthermore, there is no regular correlation between the changes of chloride content and soil sampling depth which revealed that the distribution of chloride ions in soil samples does not depend on the depths of the buried pipelines, which might be controlled by other physical or environmental factors.

On the other hand, about $2 / 3^{\text {rd }}$ of the thirty soil specimens contained $<100 \mathrm{ppm}$ of sulfate ions that are rated as EIC, while remaining $1 / 3^{\text {rd }}$ sample specimens rated as $\mathrm{MiC}$ to the metallic pipelines in soils having the sulfate ions within the range of 100-200 ppm, as shown in Figure 4 (b). The rating of soil samples as ElC or MiC is based on the ASTM international publications $[24,45]$. Besides, the effect of the sampling depth on the sulfate amount in the soil samples is observed. The concentration of sulfate ions is generally increased with increasing sampling depth and hence a maximum amount of sulfate ions is estimated in the soil specimens of $1.5 \mathrm{~m}$ depth of all six sampling sites.

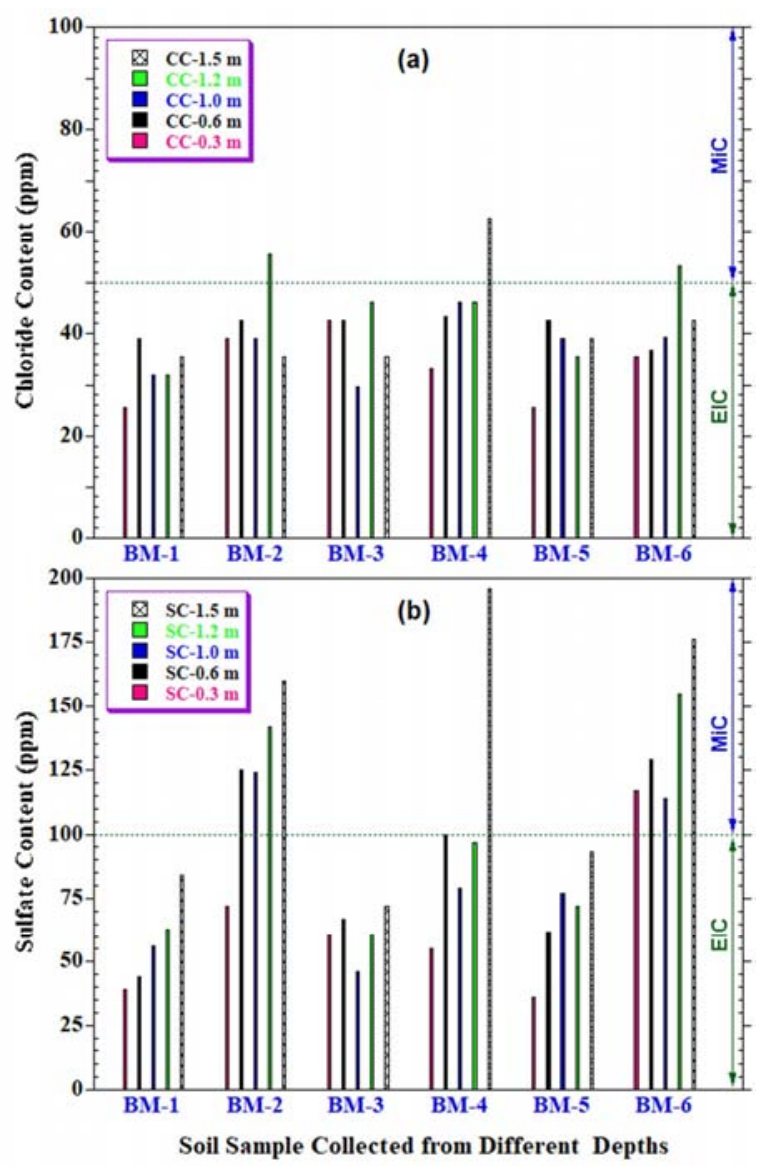

Figure 4. (a) Chloride and (b) sulfate content in soil samples.

\subsection{Correlation Between Soil Properties}

Soil moisture has a profound correlation with soil resistivity. Water retaining capacity of a dry or sandy soil is generally very low and hence is typically less-corrosive, while clayey soil that holds more amounts of water shows low resistivity and hence more corrosive to the buried- 
galvanized steel and cast iron pipelines. An inverse correlation between the soil resistivity and the moisture content in all thirty sample specimens is observed from Figure 5 (a). The soil resistivity is exponentially increased with a decrease of the amount of moisture up to $50 \%$. The empirical relationship between the resistivity (y) and the moisture (x) in soil samples is found to be as; $y=3.37 \times 10^{4}$. $1.78 \times 10^{4} \log (\mathrm{x})$ with the regression coefficient $\left(=\mathrm{R}^{2}\right)$ of 0.677 . It was observed a good correlation between the soil corrosivity towards the buried-metallic materials and the nature of decreasing the soil resistivity with increasing the moisture content in it was reported in the literature $[31,50]$.

A fairly good relationship between the soil resistivity and the sum of both chloride and sulfate ions is found, as shown in Figure 5 (b). These results revealed that moisture, chloride and sulfate contents in soil contributed to decrease the soil resistivity or to increase the soil corrosivity to the buriedgalvanized steel and cast iron pipes in the study areas of Kathmandu. Moreover, the correlation between six parameters of all the soil specimens were also studied using a correlation matrix, as shown in Table 3 . It exhibits the correlation among the analyzed soil parameters at 0.05 significant levels. The highlighted values are considered for the relationship study consisting of good and strong correlation.

Table 3. Correlation matrix coefficient between estimated-soil parameters of all sample specimens.

\begin{tabular}{lllllll}
\hline Soil parameters & Moisture (\%) & $\mathbf{p H}$ & Resistivity $(\boldsymbol{\Omega} . \mathbf{c m})$ & ORP $(\mathbf{m V})$ & Chloride $(\mathbf{p p m})$ & Sulfate $(\mathbf{p p m})$ \\
\hline Moisture $(\%)$ & 1 & & & & & \\
pH & 0.0860 & 1 & & & & \\
Resistivity $(\Omega . \mathrm{cm})$ & -0.7429 & -0.0213 & 1 & 1 & & \\
ORP $(\mathrm{mV})$ & -0.1384 & 0.1578 & -0.0068 & 0.1059 & 1 & \\
Chloride (ppm) & 0.5742 & 0.1277 & -0.6072 & -0.0563 & 0.6369 & 1 \\
Sulfate (ppm) & 0.7390 & 0.1613 & -0.6613 & & \\
\hline
\end{tabular}
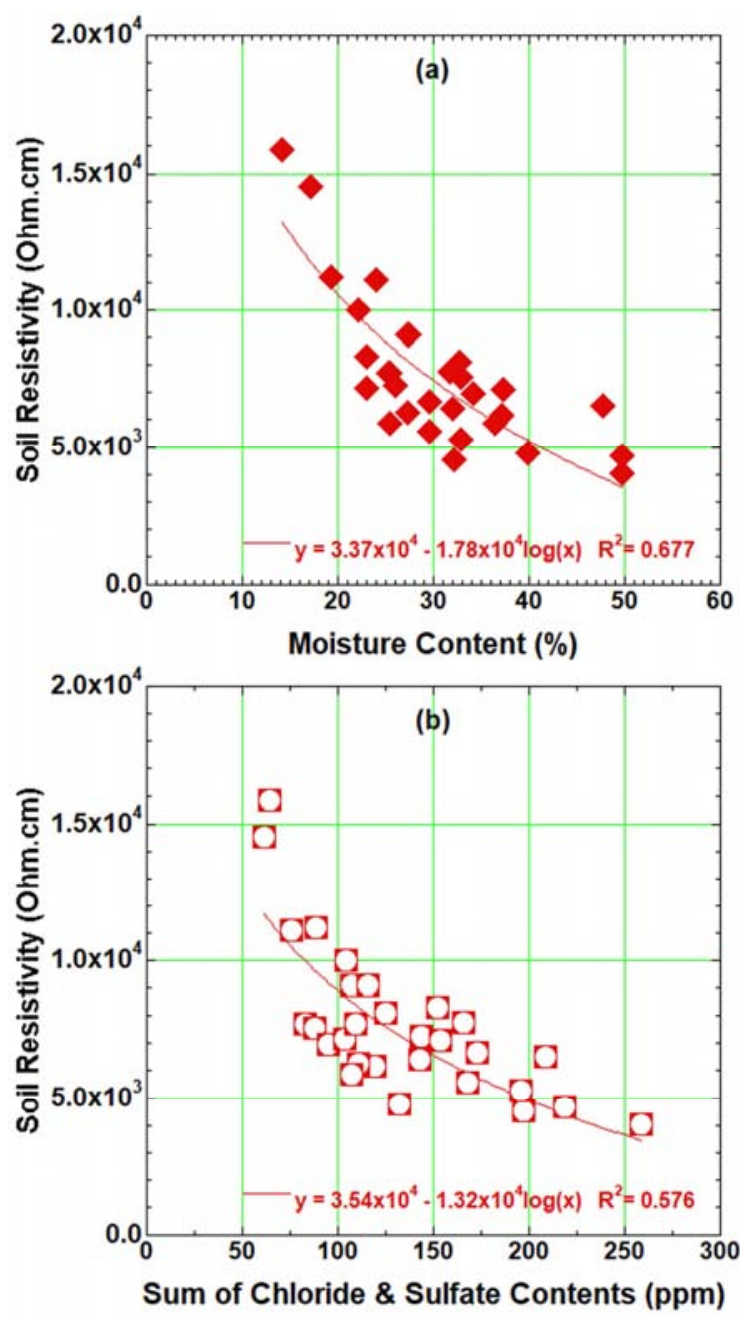

Figure 5. The empirical correlation between the soil resistivity with (a) moisture content and (b) sum of chloride and sulfate ions.
A good negative and positive correlation between moisture and resistivity, and moisture and sulfate ions, respectively, with matric coefficient values of -0.7429 and +0.7390 indicates that the high resistivity of the soil samples is mostly due to the low amount of sulfate in the soil retained-water. Such type of the negative relationship between the resistivity and the moisture content was reported in a uniform soil texture [58] which could also cause a good correlation between soil resistivity and corrosion damages, while a very weak correlation between soil resistivity and moisture content for non-uniform soil texture reported in previously published literature [47]. Similarly, a fairly good negative correlation between the soil resistivity and chloride or sulfate ions is observed from the correlation matrix table. Also, a fairly good positive matrix correlation coefficient is seen between chloride content and moisture or sulfate content in soil samples. Very weak or no-correlation exhibits between remaining other soil characteristics analyzed in the study.

\subsection{Empirical Model for Soil Corrosion Rating}

The empirical classification model was used to designate the ten sub-corrosive groups for the soil corrosion rating to the buried-metallic substances like galvanized-steel and cast iron as already described the aforementioned experimental procedures. These ten sub-corrosive groups are arranged as; ElC $<$ ElC $^{\text {plus }}<\mathrm{MiC}^{\text {minus }}<\mathrm{MiC}<\mathrm{MiC}^{\text {plus }}<\mathrm{MoC}^{\text {minus }}<\mathrm{MoC}<\mathrm{MoC}^{\text {pl }}$ ${ }^{\text {us }}<\mathrm{SevC}^{\text {minus }}<\mathrm{SevC}$. For the identification of the subcorrosive groups of soil samples, the presence of cumulative points up to 4 (i.e. $\mathrm{CP}=4$ ) in any one group is enough to assign a specific corrosive group (i.e., ElC, MiC, MoC or SevC) distinctly in this empirical model. The specific corrosive groups again could be classified into its subcorrosive groups, indicated by the superscripted plus ( ${ }^{\text {plus }}$ ) and superscripted minus (minus) in the respective specific group if such a group has more factors. 
For example, the CP for the II (mildly corrosive-MiC) group is 4 for the soil specimens collected from 1.2 or $1.5 \mathrm{~m}$ depth of the MB-1 sampling site (i.e., 2-4-0-0) is sufficient to classify it to the $\mathrm{MiC}$ corrosive group firstly. Again, if we check the remaining $\mathrm{CP}=2$ which belongs to I (essentially less corrosion) group, and hence this soil specimen could be classified as $\mathrm{MiC}^{\text {minus }}$ sub-corrosion group because it is considered that this sample specimen should be more corrosive than that of the soil sample belonging to the MiC sub-corrosive group. In some soil samples, equal numbers of the $\mathrm{CP}$ (i.e., $\mathrm{CP}=3$ ) in tow corrosion groups might be assigned of both specific corrosion groups as illustrated in Table 4. In a likewise manner, all thirty soil sample specimens are classified into different sub-corrosive groups, as summarized in Table 4. Despite this, the proposed empirical model cannot exactly assign any of these ten corrosive sub-groups if each corrosion group has $2 \mathrm{CP}$ values (for example, 2-2-2-0, 0-2-2-2; 2-0-2-2 or 2-2-0-2) despite of the fact that all the analyzed samples specimens do not show such situation in the present study. In such a circumstance, it could be considered a corrosion-prone area in the future [4].
The results shown in Table 4 outlined that the corrosiveness of the soil samples is generally found to be increased with sampling depth, most probably due to the increase of both soil moisture and sulfate ions and decrease of soil resistivity with depth. This implies the role of burying depth on the galvanized-steel and cast iron water pipelines lifetime. Besides, all the analyzed soil sample specimens have belonged to only two specific corrosive groups, i.e., essentially less corrosive and mildly corrosive, with their sub-corrosive groups in the study areas of BudhanilkanthaMaharajganj roadways. Consequently, it makes oneself useful for making a soil corrosion risk assessment map of the study areas that can ultimately be advantageous to identify specific sites that would be susceptible to a given corrosion scenario. Results also indicate that galvanized-steel and cast iron pipes with polyethylene encasement, consisting of a sheet of polyethylene wrapped over the pipe or the use of gravel/sand around the pipelines at the time of installation could be recommended for their protective measures as recommended by various standards $[29,53,59,60]$.

Table 4. Results of these six soil parameters, cumulative point (CP) values, and sub-corrosive groups of soil samples.

\begin{tabular}{|c|c|c|c|c|c|c|c|c|c|c|c|c|}
\hline \multirow[b]{2}{*}{ Sites } & \multirow[b]{2}{*}{ Depth (m) } & \multicolumn{6}{|c|}{ Corrosive class of each soil parameter } & \multicolumn{5}{|c|}{ CP to each class } \\
\hline & & pH & MC & $\rho$ & ORP & $\mathrm{Cl}^{-}$ & $\mathrm{SO}_{4}{ }^{2-}$ & I & II & III & IV & Sub-corrosive groups \\
\hline \multirow{4}{*}{ BM-1 } & 0.3 & I & $\mathrm{I}$ & I & II & I & $\mathrm{I}$ & 5 & 1 & 0 & 0 & ElC \\
\hline & 0.6 & I & II & II & II & I & $\mathrm{I}$ & 3 & 3 & 0 & 0 & $\mathrm{MiC}^{\text {minus }} \equiv \mathrm{ElC}^{\text {plus }}$ \\
\hline & 1.2 & II & II & II & II & I & I & 2 & 4 & 0 & 0 & $\mathrm{MiC}^{\text {minus }}$ \\
\hline & 1.5 & II & II & II & II & I & I & 2 & 4 & 0 & 0 & $\mathrm{MiC}^{\text {minus }}$ \\
\hline \multirow{4}{*}{ BM-2 } & 0.3 & I & II & II & II & I & I & 3 & 3 & 0 & 0 & $\mathrm{MiC}^{\text {minus }} \equiv \mathrm{ElC}^{\text {plus }}$ \\
\hline & 1.0 & II & II & III & I & I & II & 2 & 3 & 1 & 0 & $\mathrm{MiC}$ \\
\hline & 1.2 & II & II & II & I & II & II & 1 & 5 & 0 & 0 & $\mathrm{MiC}$ \\
\hline & 1.5 & II & II & II & I & I & II & 2 & 4 & 0 & 0 & $\mathrm{MiC}^{\text {minus }}$ \\
\hline \multirow{5}{*}{ BM-3 } & 0.3 & I & I & II & I & I & I & 5 & 1 & 0 & 0 & ElC \\
\hline & 0.6 & II & II & II & I & I & $\mathrm{I}$ & 3 & 3 & 0 & 0 & $\mathrm{MiC}^{\text {minus }} \equiv \mathrm{ElC}^{\text {plus }}$ \\
\hline & 1.0 & II & I & I & I & I & I & 5 & 1 & 0 & 0 & ElC \\
\hline & 1.2 & II & II & II & I & I & I & 3 & 3 & 0 & 0 & $\mathrm{MiC}^{\text {minus }} \equiv \mathrm{ElC}^{\text {plus }}$ \\
\hline & 1.5 & I & II & II & I & I & I & 4 & 2 & 0 & 0 & ElC ${ }^{\text {plus }}$ \\
\hline \multirow{4}{*}{ BM-4 } & 0.6 & II & II & II & II & I & I & 2 & 4 & 0 & 0 & $\mathrm{MiC}^{\text {minus }}$ \\
\hline & 1.0 & II & II & II & I & I & I & 3 & 3 & 0 & 0 & $\mathrm{MiC}^{\text {minus }} \equiv \mathrm{ElC}^{\text {plus }}$ \\
\hline & 1.2 & II & II & II & II & I & I & 2 & 4 & 0 & 0 & $\mathrm{MiC}^{\text {minus }}$ \\
\hline & 1.5 & II & III & III & II & II & II & 0 & 4 & 2 & 0 & $\mathrm{MiC}^{\text {plus }}$ \\
\hline \multirow{5}{*}{ BM-5 } & 0.3 & II & I & I & II & I & I & 4 & 2 & 0 & 0 & ElC ${ }^{\text {plus }}$ \\
\hline & 0.6 & II & I & II & I & I & I & 4 & 2 & 0 & 0 & ElC ${ }^{\text {plus }}$ \\
\hline & 1.0 & III & II & II & I & I & I & 3 & 2 & 1 & 0 & ElC ${ }^{\text {plus }}$ \\
\hline & 1.2 & II & II & II & II & I & I & 2 & 4 & 0 & 0 & $\mathrm{MiC}^{\text {minus }}$ \\
\hline & 1.5 & II & II & III & II & I & I & 2 & 3 & 1 & 0 & $\mathrm{MiC}^{\text {minus }}$ \\
\hline \multirow{5}{*}{ BM-6 } & 0.3 & II & I & II & I & I & II & 3 & 3 & 0 & 0 & $\mathrm{MiC}^{\text {minus }} \equiv \mathrm{ElC}^{\text {plus }}$ \\
\hline & 0.6 & II & II & II & I & I & II & 2 & 4 & 0 & 0 & $\mathrm{MiC}^{\text {minus }}$ \\
\hline & 1.0 & II & II & II & I & I & II & 2 & 4 & 0 & 0 & $\mathrm{MiC}^{\text {minus }}$ \\
\hline & 1.2 & II & III & II & II & II & II & 0 & 5 & 1 & 0 & $\mathrm{MiC}$ \\
\hline & 1.5 & II & III & III & II & I & II & 1 & 3 & 2 & 0 & $\mathrm{MiC}^{\text {plus }}$ \\
\hline
\end{tabular}

\section{Conclusion}

Six parameters of thirty soil specimens, collected from 0.3 to $1.5 \mathrm{~m}$ sampling depths of six sites around the Budanilkantha-Maharajganj roadways (Kathmandu valley), were estimated to investigate the effects of depths on the soil corrosivity to the buried-galvanic steel and cast iron pipelines using an empirical model herein. Experimental outcomes indicated that all most all the soil specimens rated as mildly corrosive and essentially less corrosive, even though a very few specimens belong to the moderately corrosive group as 
regards the high moisture concentration and conductivity. A fairly to good correlation is observed between the soil resistivity and other soil parameters of moisture, chloride and sulfate content. It assumes that the rate of corrosion of soils to the underground metallic pipes is generally increased with sampling depth based on the empirical model analysis. The implementation of the polyethylene encasement process or the use of gravel and/or sand around the underground pipes before their installation in the study areas seems to be effective to increase such pipelines' life periods.

\section{Funding}

This work is partially supported by the Nepal Academy of Science and Technology (NAST) for providing the NAST PhD scholarship to KP Dahal and the NAST Research Grant to J Bhattarai.

\section{Author Contribution}

AP and JB designed the experiment, and sample collection, data analysis and results are summarized by AP, $\mathrm{KPD}$ and $\mathrm{DKC}$. The first draft of the manuscript was written by AP \& JB, and all authors read and approved the final manuscript.

\section{Conflict of Interest}

The authors declare that they have no conflict of interest.

\section{References}

[1] Ricker RE (2010) Analysis of pipeline steel corrosion data from NBS (NIST) studies conducted between 1922-1940 and relevance to pipeline management. Journal of Research of the National Bureau of Standards 115 (5): 373-392. https://doi.org/10.6028/jres.115.026

[2] Revie RW, Uhlig HH (2008) Corrosion and corrosion control; an introduction to corrosion science and engineering. $4^{\text {th }}$ ed., New Jersey, USA: John Wiley \& Sons Inc.

[3] Arriba-Rodriguez L-de, Villanueva-Balsera J, OrtegaFernandez F, Rodriguez-Perez FO (2018) Methods to evaluate corrosion in buried steel structures: a review. Metals 8: 334 (21pp). https://doi.org/10.3390/met8050334

[4] Taghipour M, Lashkaripour GR, Ghafoori M, Hafezimoghaddas N (2016) Evaluating the soil corrosion of Bushehr, Iran, based on a new classification system for corrosive soils. Anti-Corrosion Methods and Material 63 (5): 347-354. http://dx.doi.org/10.1108/ACMM-01-2015-1489

[5] Bonds RW, Barnard LM, Horton AM, Oliver GL (2005) Corrosion and corrosion control of iron pipe: 75 years of research. AWWA Journal 97 (6): 88-98. https://doi.org/10.1002/j.1551-8833.2005.tb10915.x

[6] Su H, Mi S, Peng X, Han Y (2019) The mutual influence between corrosion and the surrounding soil microbial communities of buried petroleum pipelines. RSC Advances 9: 18930-18940. https://doi.org/10.1039/c9ra03386f
[7] Saupi SRA, Haris NHA, Masri MN, Sulaiman MA, Abubakar MB, Amini MM, Mohammed M, Yusuf NAN (2016) Effects of soil physical properties to the corrosion of underground pipelines. Material Science Forum 840: 309-314. https://doi.org/10.4028/www.scientific.net/MSF.840.309

[8] Costa Pereira da RF, Oliveira de ESD, Andrade Lima de MAG, Cezar Brasil SLD (2015) Corrosion of galvanized steel under different soil moisture contents. Material Research 18 (3): 563-568. http://dx.doi.org/10.1590/1516-1439.341714

[9] Bhattarai J (2013) Study on the corrosive nature of soil towards the buried structures. Scientific World 11 (11): 43-47. http://dx.doi.org/10.3126/sw.v11i11.8551

[10] Bhandari PP, Dahal KP, Bhattarai J (2013) The corrosivity of soil collected from Araniko highway and Sanothimi areas of Bhaktapur. Journal of Institute of Science and Technology 18 (1): $71-77$. https://www.researchgate.net/publication/311560647. (Accessed on July 15, 2020).

[11] Dahal KP, KC D, Bhattarai J (2014) Study on the soil corrosivity towards the buried water supply pipelines in Madhyapur Thimi municipality; Bhaktapur. Bibechana 11: 94-102. http://dx.doi.org/10.3126/bibechana.v11i0.10387

[12] Liu HW, Dai Y, Cheng YF (2020) Corrosion of underground pipelines in clay soil with varied soil layer thicknesses and aerations. Arabian Journal of Chemistry 13 (2): 3601-3614. https://doi.org/10.1016/j.arabjc.2019.11.006

[13] Liu HW, Meng G, Li W, Gu T, Liu H (2019) Microbiologically influenced corrosion of carbon steel beneath a deposit in $\mathrm{CO}_{2}$-saturated formation water containing Desulfotomaculum nigrificans. Frontiers of Microbiology 10: 1298. https://doi.org/10.3389/fmicb.2019.01298

[14] Oudbashi O (2018) A methodological approach to estimate soil corrosivity for archaeological copper alloy artifacts. Heritage Science 6: 2 pp 15. https://doi.org/10.1186/s40494018-0167-4

[15] Folkman S (2018) Water main break rates in the USA and Canada: a comprehensive study. In: Mechanical and aerospace engineering faculty publications, Paper No. 174, Utah State University, UT, USA, pp 1-47. https://digitalcommons.usu.edu/mae_facpub/174

[16] Hou Y, Lei D, Li S, Yang W, Li C (2016) Experimental investigation in corrosion effect on mechanical properties of buried metal pipes. International Journal of Corrosion 2016: 72 (ID: 58008372). https://doi.org/10.1155/2016/5808372

[17] Ossai CI, Boswell B, Davies IJ (2015) Pipeline failures in corrosive environments- a conceptual analysis of trends and effects. Engineering Failure Analysis 53: 36-58. http://dx.doi.org/10.1016/j.engfailanal.2015.03.004

[18] Kim M, Inakazu T, Kaizumi K, Koo J (2013) Statistical approach for corrosion prediction under fuzzy soil environment. Environmental Engineering Research 18 (1): 37-43. https://doi.org/10.4491/eer.2013.18.1.037

[19] Decker JB, Rollins KM Ellsworth JC (2008). Corrosion rate evaluation and prediction for piles based on long term field performance. Journal of Geotechnical and Geo-environmental $\begin{array}{llll}\text { Engineering } & 134 & \text { (3): 341-351. }\end{array}$ https://doi.org/10.1061/(ASCE)1090-0241(2008)134:3(341) 
[20] Dhakal YR, Dahal KP, Bhattarai J (2014) Investigation on the soil corrosivity towards the buried water supply pipelines in Kamerotar town planning areas of Bhaktapur, Nepal. Bibechana 10: 82-91. http://dx.doi.org/10.3126/bibechana.v10i0.8454

[21] Bhattarai J, Paudyal D, Dahal KP (2016) Study on the soil corrosivity towards the buried-metallic pipes in Kathmandu and Chitwan Valley of Nepal. In: Proceedings of the $17^{\text {th }}$ Asian-Pacific Corrosion Control Conference ( $17^{\text {th }}$ APCC), Paper No. 17039, 27-30 January. IIT Bombay, Mumbai, India, pp 1-12.

https://www.researchgate.net/publication/293178472. (Accessed on August 2 2020).

[22] Dahal KP, Bhattarai J (2016) Study on the soil corrosivity towards the underground pipes in Sinamangal-BaneshworMaitidevi-Bagbazar roadway areas of Kathmandu, Nepal. In Proceedings of CORCON 2016, Paper No. PP-11, Publication of NIGIS/NACE, 18-21 September, New Delhi, pp. 1-8. https://www.researchgate.net/publication/308605923. (Accessed on August 2 2020).

[23] ASTM G187-18. (2018). Standard test method for measurement of soil resistivity using the two-electrode soil box method. In: Annual Book of ASTM Standards Vol. 03.02, West Conshohocken, PA, USA: ASTM International.

[24] Palmer J (1989) Environmental characteristics controlling the soil corrosion of ferrous piping. In: Chaker V, Palmer J (eds) Effects of soil characteristics on corrosion, West Conshohocken, PA, USA: ASTM International, pp 5-16. https://doi.org/10.1520/STP19706S

[25] Palmer J (1990) Field soil corrosivity testing- engineering considerations. In: Baboian R, Dean S (eds), Corrosion testing and evaluation: silver anniversary volume, West Conshohocken, PA, USA: ASTM International, pp 125-138. https://doi.org/10.1520/STP39185S

[26] NACE SP0169 (2013) Control of external corrosion on underground or submerged metallic piping systems. Houston, Texas, USA: NACE International, pp 60.

[27] NACE RP0502-2002 (2002) Pipeline external corrosion direct assessment methodology. Houston, Texas, USA: NACE International, pp 62.

[28] ANSI/AWWA C151/A21.5 (2002) American national standard for ductile-iron pipe, centrifugally cast, for water or other liquids. Catalog No. 43151, American National Standards Institute/American Water Works Association, Denver, USA.

[29] ANSI/AWWA C105/A21.5 (1999) American national standard for polyethylene encasement for ductile-iron pipe systems. Catalog No. 43105, American National Standards Institute/American Water Works Association, Denver, USA.

[30] Melchers RE, Petersen RB, Wells T (2019) Empirical models for long-term localized corrosion of cast iron pipes buried in soils. Corrosion Engineering, Science and Technology 54 (2): 1-10. https://doi.org/10.1080/1478422X.2019.1658427

[31] Dahal KP, Karki RK, Bhattarai J (2018) Evaluation of corrosivity of soil collected from central part of Kathmandu metropolis (Nepal) to water supply metallic pipes. Asian Journal of Chemistry 30 (7): 1525-1530. https://doi.org/10.14233/ajchem.2018.21211

[32] Regmi SK, Dahal KP, Bhattarai J (2015) Soil corrosivity to the buried-pipes used in Lalitpur, Kathmandu valley, Nepal. Nepal Journal of Environmental Science 3 (1): 15-20. https://doi.org/10.3126/njes.v3i0.22730

[33] Velazquez JC, Caleyo F, Valor A, Hallen JM (2009) Predictive model for pitting corrosion in buried oil and gas pipelines. Corrosion 65 (5): 332-342. https://doi.org/10.5006/1.3319138

[34] Ganiyu SA, Olurin OT, Ajibodu KA, Badmus BS, Ajayi AO (2018) Assessment of the degree of external corrosion of buried water pipelines and source identification of heavy metals due to surrounding soil conditions in a humid environment. Environmental Earth Sciences 77: 443-460. https://doi.org/10.1007/s12665-018-7611-3

[35] Doyle G, Seica MV, Grabinsky MWF (2003) The role of soil in the external corrosion of cast iron water mains in Toronto, Canada. Canadian Geotechnical Journal 40 (2): 225-236. https://doi.org/10.1139/t02-106

[36] Escalante E (1989) Concepts of underground corrosion. In: Chaker V, Palmer J (ed.) Effect of soil characteristics on corrosion. West Conshohocken, PA, USA: ASTM International, pp. 81-94. https://doi.org/10.1520/STP19710S

[37] ASTM D4959-16. (2016). Standard test method for determination of water (moisture) content of soil by direct heating. In: Annual Book of ASTM Standards Vol. 04.08, West Conshohocken, PA, USA: ASTM International. https://doi.org/10.1520/D4959-16

[38] ASTM G51-18 (2018) Standard test method for measuring the $\mathrm{pH}$ of soil for use in corrosion testing. In: Annual Book of ASTM Standards Vol. 03.02, West Conshohocken, PA, USA: ASTM International. https://doi.org/10.1520/G005118

[39] ASTM G200-09 (2014) Standard test method for measurement of oxidation-reduction potential (ORP) of soil. In: Annual Book of ASTM Standards Vol. 03.02, West Conshohocken, PA, USA: ASTM International. https://doi.org/10.1520/G0200-09R14

[40] AASHTO T 291-94 (2018) Standard method of test for determining water-soluble chloride ion content in soil. American Association of State Highway and Transportation Officials, Washington, D. C., USA.

[41] AASHTO T 290-95 (2016) Standard method of test for determining water-soluble sulfate ion content in soil. American Association of State Highway and Transportation Officials, Washington, D. C, USA.

[42] USDA (1998). Soil Quality Indicators: $\mathrm{pH}$, The US Department of Agriculture, Natural Resources Conservation Service, Washington, DC, USA. https://www.nrcs.usda.gov/Internet/FSE_DOCUMENTS/nrcs 142p2_052208.pdf. (Accessed on July 2, 2020).

[43] Jun J, Unocic KA, Petrova MV, Shipilov SA, Carvalhaes T, Thakur G, Piburn J, Pint BA (2019) Methodologies for evaluation of corrosion protection for ductile iron pipe. ORNL/TM-2017/144, Oak Ridge National Laboratory, Oak Ridge, USA, $\quad$ pp $1-73$. https://www.researchgate.net/publication/337844496

[44] Starkey RL, Wight KM (1947) Anaerobic corrosion of iron in soil. Corrosion 3 (5): 227-232. https://doi.org/10.5006/00109312-3.5.227 
[45] Jones DA (1996) Principles and prevention of corrosion. $2^{\text {nd }}$ ed., Prentice-Hall.

[46] Benmoussa A, Hadjel H, Traisnel M (2006) Corrosion behavior of API 5L X-60 pipeline steel exposed to nearneutral $\mathrm{pH}$ soil simulating solution. Materials and Corrosion 57: 771-777. http://dx.doi.org/10.1002/maco.200503964

[47] Cole I, Marney D (2012) The science of pipe corrosion: a review of the literature on the corrosion of ferrous metals in soils. Corrosion Science 56: 5-16. https://doi.org/10.1016/j.corsci.2011.12.001

[48] Shreir LL, Jarman RA, Burstein GT (2000). Corrosion: metal/environment Reactions, Volume 1. Oxford, UK: Butterworth-Heinemann.

[49] Kalyani DS, Rajesh V, Reddi EUB, Kumar KC, Rao SS (2017) Correlation between corrosion indices and corrosiveness of groundwater: a study with reference to selected areas of Krishna District, Andhra Pradesh, India. Environmental Earth Sciences 76: 568. https://doi.org/10.1007/s12665-017-6908-y

[50] Denison IA, Romanoff M (1952) Corrosion of galvanized steel in soils. Journal of Research of the National Bureau of Standards 49: 299-314. http://dx.doi.org/10.6028/jres.049.031

[51] Logan KH, Ewing SP, Denison IA (1937) Soil corrosion testing. In: Speller F (ed) Symposium on corrosion testing procedures, West Conshohocken, PA, USA: ASTM International, pp 95-128. https://doi.org/10.1520/STP47836S

[52] Logan KH, Growsky VA (1931) Rates of corrosion and pitting of bare ferrous specimens. In: Soil corrosion studies 1930, The US Department of Commerce, Washington DC, USA: Government Printing Office.

[53] NAC (2009) Report on the review of the bureau of reclamation's corrosion prevention standards for ductile iron pipe. In: Johnson DW, Bianchetti R, Firlds RJ, Handwerker
CA, Brien JO, Keefe MO, Sagues JR, Spickelmire WS, Trejo D(eds), National Academy of Sciences, Washington, USA: The National Academy Press, pp 1-186.

[54] Arzola S, Mendoza-Flores J, Duran-Romero R, Genesca J (2006) Electrochemical behavior of API X70 steel in hydrogen sulfide-containing solutions. Corrosion 62: 433443. https://doi.org/10.5006/1.3278.

[55] Li SY, Kim YG, Jeon KS, Kho YT, Kang T (2001) Microbiologically influenced corrosion of carbon steel exposed to anaerobic soil. Corrosion 57: 815-828. https://doi.org/10.5006/1.3280616

[56] Hamilton WA (2003) Micro-biologically influenced corrosion as a model system for the study of metal microbe interactions: a unifying electron transfer hypothesis. Biofouling 19 (1): 65 76. https://doi.org/10.1080/0892701021000041078

[57] Jack TR (2002) Biological corrosion failures. In: Failure analysis and prevention, ASM handbook, Materials Park, $\mathrm{OH}$, USA: ASM International, pp 881-898.

[58] Calamita G, Brocca L, Perrone A, Piscitelli S, Lapenna V, Melone F, Moramarco T (2012) Electrical resistivity and TDR methods for soil moisture estimation in Central Italy test-sites. Journal of Hydrology 454/455: 101-112. http://dx.doi.org/10.1016/j.jhydrol.2012.06.001

[59] Calhoun TR, Harris DW, Keith J, Fuerst RP (2004) Corrosion considerations for buried metallic water pipe. Technical Memorandum 8140-CC-2004-1, US Department of the Interior Bureau of Reclamation, Denver, Colorado, USA: Technical Service Center.

[60] ASTM A674-18 (2018) Standard practice for polyethylene encasement for ductile iron pipe for water and other liquids. West Conshohocken, PA, USA: ASTM International. 